\title{
Aktorzy interpretacji
}

Paweł Bohuszewicz

TEKSTY DRUGIE 2021, NR 2, S. 101-117

DOI: 10.18318/td.2021.2.6 | ORCID: 0000-0003-0033-2876

1.

Teoretycy literatury w Polsce nie dyskutują już o interpretacji. Wciąż o niej piszą, nie prowokuje to jednak szerszego odzewu członków literaturoznawczej wspólnoty. A jeszcze niedawno było inaczej... Niegdysiejsze dyskusje wokół tego problemu sprowadzały się do prezentacji dwóch stanowisk: realizmu czy też esencjalizmu - czyli stanowiska, zgodnie z którym teksty mają immanentne znaczenie, możliwe do odtworzenia bez ryzyka deformacji przez sytuację poznawczą - oraz konstruktywizmu społeczno-kulturowego czy też antyesencjalizmu, w myśl którego immanentne znaczenia nie istnieją, są bowiem relatywne względem historycznie określonej sytuacji poznawczej'.

1 Od tej pory, kiedy będę pisał o konstruktywizmie społeczno-kulturowym, będę używał określenia "konstruktywizm", ważne jest jednak, żeby czytelnik pamiętał, że mam na myśli ten jeden specyficzny jego wariant, którego bliższą charakterystykę podam dalej (syntetyczny opis wariantów konstruktywizmu zob. P. Bohuszewicz, M. Cyzman Wokół pojęcia konstruktywizmu, "Litteraria Copernicana” 2016 nr 3:

Paweł Bohuszewicz - dr hab., Wydział Humanistyczny Uniwersytetu Mikołaja Kopernika wToruniu; interesuje się teorią i historią dawnej powieści w Polsce, teorią interpretacji i teorią aktora-sieci; długim trwaniem polskiej kultury szlacheckiej. Ostatnio opublikował Od „,romansu"do powieści. Studia o polskiej literaturze narracyjnej (druga połowa XVII wieku - pierwsza połowa XIX wieku), Toruń 2016. Kontakt: bohusz@umk.pl 
Opozycja, o której mowa, jest pochodną innego rozróżnienia, wspominanym przez Brunona Latour na początku Nadziei Pandory. Według niego historia nowoczesnej epistemologii, od Kartezjusza począwszy, a na konstruktywizmie społecznym skończywszy, to opowieść o relacji, na którą składają się dwa elementy: „zewnętrzny świat” i „umysł”. Próbowano budować między nimi połączenia za pomocą trzeciego elementu, czyli „języka”, który może działać na dwa sposoby: albo przenosić jakieś cechy zewnętrznego świata do wnętrza umysłu (wariant realistyczny), albo na odwrót: narzucać na bezkształtną i niedostępną poznaniu rzeczywistość to, co na jej temat wykoncypuje umysł (wariant konstruktywistyczny). Problem z obydwoma stanowiskami polega na tym, że stanowią one fikcje, których nie da się wywieść z praktyki naukowej. Pokazuje to Latour we wspomnianej przed chwilą pracy. Zawarte w niej studia przypadków pokazują, że badacz, mierząc się z konkretnymi problemami, nie zasypuje zdaniami przepaści między „umysłem” a „światem zewnętrznym”, lecz uczestniczy w pewnym zdarzeniu, którego wszyscy uczestnicy składają sobie propozycje artykulacji i w którego efekcie wszyscy zostają zmienieni. W czwartym i piątym rozdziale Nadziei Pandory Latour wyjaśnia swoją koncepcję w trybie drobiazgowej analizy odkrycia fermentacji przez Pasteura. Zadając pytanie, kto działa w tym zdarzeniu, odpowiada, że oczywiście „P a s t e u r, ponieważ obsypuje, podgrzewa, filtruje i obserwuje”. Działają jednak także „[d]rożdż e kwas u mlekowe go, bo szybko rosną, zużywając swoje pożywienie, zyskując na sile [...] i przystępując do rywalizacji z innymi podobnymi bytami rosnącymi jak rośliny na tym samym kawałku gruntu"2. Opisana sytuacja pokazuje, że poznanie nie jest grą o sumie zerowej między dwoma elementami („światem” i „umysłem”), w której aktywny może być tylko jeden element, ponieważ aktywni pozostają w niej wszyscy uczestnicy, nazwani przez Latoura aktorami.

Jak Latourowskie ustalenia na temat praktykowania nauki przekładają się na problem praktyki interpretacji? Jej dotychczasowe najpopularniejsze

Konstruktywizm w literaturoznawstwie, red. P. Bohuszewicz, M. Cyzman). Tomasz Szymon Markiewka wspomina, że istniała również trzecia strona sporu: między logocentrystami (czyli tymi, którzy twierdzą, że istnieje "spójna, zamknięta i całościowa budowa dzieł literackich") i antylogocentrystami (czyli tymi, którzy negują istnienie tych właściwości). Zob. T.S. Markiewka Literaturoznawczy spór o interpretację. Analiza wybranych dwudziestowiecznych koncepcji teoretycznych, Wydawnictwo Naukowe UMK, Toruń 2016, s. 33. Nie wymieniam jej w swoim tekście, uważam bowiem, że w polskich "wojnach o interpretację" miała ona marginalne znaczenie.

2 B. Latour Nadzieja Pandory. Eseje o rzeczywistości w studiach nad naukg, przeł. K. Abriszewski i in., Wydawnictwo Naukowe UMK, Toruń 2013, s. 170-171. 
koncepcje implikują, że interpretacja to gra o sumie zerowej, czyli taka, w której dwie strony walczą ze sobą, by przemóc jedną ze stron. Diametralnie odmienne w przyznawaniu sprawczości, nie różnią się w uznaniu, że tak naprawdę sprawczy jest zawsze jeden aktor: tekst (interpretacja jawi się wówczas jako odkrywanie znaczeń i sensów, które znajdują się w znakach) lub czytelnik (zgodnie z najbardziej radykalną, Fishowską wersją tego poglą$\mathrm{du}$, nie tylko znaczenie, lecz także sam tekst jest produktem interpretacji) ${ }^{3}$. Nie uważam, jak Andrzej Szahaj, że dyskusję między tymi stanowiskami należy porzucić jako niekonkluzywną , ale że można ją zamknąć, pokazując, iż interpretacja nie jest ani realistycznie rozumianym odkrywaniem, ani konstruktywistycznie pojętym konstruowaniem sensu. Czym zatem jest?

Zgadzając się z Latourem, że aby odpowiedzieć, czym coś jest, należy najpierw określić, jak to coś działa, na początku zaprezentuję własne studium będące zapisem cudzej praktyki interpretacyjnej, a dopiero na końcu postaram się odpowiedzieć na postawione pytanie. Aktorem, za którym podążę, będzie dokonana przez Teresę Michałowską w Średniowieczu interpretacja archaicznej części Bogurodzicy. Będąc typową instytucjonalną lekturą tekstu, jak by powiedział Barthes, klasycznego ${ }^{5}$, może ona posłużyć za prototyp reprezentujący ogólniejsze mechanizmy interpretacji literaturoznawczej.

3 Z jednej strony zgadzam się z tymi, którzy uważają, że literaturoznawczy spór między esencjalistami i antyesencjalistami został wymyślony przez antyesencjalistów, aby tym mocniej wybrzmiały ich stwierdzenia (tak utrzymywali np. Henryk Markiewicz [Staroświeckie glosy, "Teksty Drugie" 1997 nr 6, s. 46] czy Ryszard Nycz [Zatargi graniczne, tamże, s. 3]). Żaden, nawet najbardziej konserwatywny, teoretyk interpretacji nie mówił nigdy o "tekście samym w sobie" czy "samoobecnym znaczeniu", każdy bowiem doskonale wie, iż tekst jest tworem intencjonalnym, co znaczy, że jego specyfiki należy poszukiwać w relacji między nim samym a jego zewnętrzem, np. intencją autora czy tak lub inaczej pojmowanym kontekstem. Czy zatem antyesencjaliści sfingowali literaturoznawczy spór o interpretację? Oczywiście nie. O ile każdy teoretyk literatury będzie w kwestii interpretacji intuicyjnym "konstruktywistą" (twierdząc po prostu, że znaczenie nie płynie do nas bezpośrednio z liter, ale jest efektem takiego lub innego ukontekstowienia, a więc takiej czy innej interpretacji), o tyle trudno nie zauważyć niekonsekwencji, którą odsłania retoryka ich tekstów, zbudowanych na metaforach esencjalistycznych, implikujących zupełnie inną wizję interpretacji.

4 Zob. A. Szahaj O interpretacji, Universitas, Kraków 2014, s. 99-100.

5 Zob. R. Barthes S/Z, przeł. M.P. Markowski, M. Gołębiewska, Wydawnictwo KR, Warszawa 1999, S. 38 .

6 Pojęcie interpretacji instytucjonalnej wprowadziła Marzenna Cyzman, by odróżnić nieprofesjonalną czynność ujmowania czegoś jako czegoś od czynności interpretowania w ramach 
Antyesencjalistyczna koncepcja interpretacji w tej wersji, którą rozpowszechnili Fish i Szahaj, wytworzyła „zdrowy rozsądek” pokaźnej części dzisiejszych teoretyków literatury. Kiedy myślimy o interpretacji, jesteśmy konstruktywistami. Jak zauważył Tomasz Szymon Markiewka, u Fisha i Szahaja pojęcie interpretacji rozumiane jest na dwa sposoby: szeroki i wąski'. W pierwszym jest ona tożsama z wszelkim ludzkim poznaniem, które polega na umieszczaniu tego, co rozumiane, w jakichś kontekstach. Koncepcja ta jest w gruncie rzeczy banalna i, co pokazuje Markiewka, da się ją pogodzić z najbardziej ugruntowanymi w literaturoznawstwie zdroworozsądkowymi przekonaniami na temat interpretacji. Zgodnie z drugim, węższym i ciekawszym, rozumieniem interpretacja to narzucanie przed-sądów na to, co czytamy, przez zanurzonego w określonej wspólnocie interpretacyjnej (czy raczej wspólnotach interpretacyjnych) czytelnika. Węższe rozumienie ma o wiele dalej idące konsekwencje i nie daje się już pogodzić z tradycyjnymi poglądami na interpretację, doprowadza bowiem do "całkowitego przemodelowania teoretycznego ujęcia relacji między autorem, tekstem i czytelnikiem"'. Efektem jego przyjęcia jest unieważnienie tego rodzaju typowo literaturoznawczych rozróżnień, jak intencja autora - intencja interpretatora; interpretacja historyczna (kontekst macierzysty) - interpretacja adaptacyjna (kontekst adaptacyjny); analiza - interpretacja; nauka - krytyka itd., i zastąpienie ich monizmem, zgodnie z którym jedyne co działa, to zanurzony we wspólnocie interpretacyjnej interpretator, którego aktywność przesłania sobą intencję autora i kontekst macierzysty, uniemożliwia analizę, a całą naukę o literaturze czyni odmianą krytyki.

Choć postawa monistyczna jak każda postawa krytyczna pełni niewątpliwie odświeżającą, niejednokrotnie nawet wyzwalającą funkcję (taką, jaką na gruncie polskiego literaturoznawstwa spełniły poświęcone interpretacji teksty Szahaja i Markowskiego) ${ }^{9}$, to jednak wiąże się z nią pewien problem.

instytucji, która „wiąże się z posiadaniem określonych kompetencji, nabywanych w trakcie bycia w instytucji, oznacza zatem poruszanie się w granicach wyznaczonych przez akademickie standardy" (M. Cyzman Nieznośna płynność rzeczy. Dyskurs, retoryka, interpretacja w nie-dualizującym sposobie mówienia, Wydawnictwo Naukowe UMK, Toruń 2015, s. 176). T.S. Markiewka Fish to za mało. O ograniczeniach teorii Stanleya Fisha z perspektywy zwolennika konstruktywizmu, "Litteraria Copernicana” 2016 nr 3, s. 64.

8 Tamże.

9 Więcej na temat postawy krytycznej zob. I. Hacking Konstrukcja społeczna czego?, w: Horyzonty konstruktywizmu. Inspiracje, perspektywy, przyszłość, red. A. Derra, E. Bińczyk, J. Grygieńć, 
Mówiąc językiem Latoura: „z a s tę p u j e [sobą] to, z czego zbudowana jest [...] rzeczywistość, jakąś inną materią, tym, co społeczne, w czym «faktycznie» ma to być wbudowane"10. Konstruktywistyczny monizm zdaje się z a stępować skomplikowany i bogaty zestaw praktyk literaturoznawczych, w którym działa wielu aktorów, jedną prostą operacją, w której działa jeden aktor: zniewolony przed-sądami podmiot zamknięty w bańce wspólnoty interpretacyjnej.

Z tym właśnie przekonaniem podejmę dyskusję, starając się pokazać, że przejście od słusznego przecież stwierdzenia, iż „tekst sam w sobie nie istnieje”, do stwierdzenia „w interpretacji działa tylko interpretator" zostało wykonane zbyt szybko. Interpretacja to również inne praktyki, w których działają inni aktorzy. Wskażę ich, korzystając z teorii aktora-sieci (ANT) w jej wersji latourowskiej. ANT od dłuższego czasu jest znana na polskim gruncie, nie będę więc streszczał jej podstawowych założen'"1. Sam też wykorzystuję tylko pewne wypracowane w jej ramach pojęcia (głównie te pojawiające się w Nadziei Pandory Latoura) i coś, co można by nazwać ANT-owską wyobraźnią, dla której najważniejsze są nakaz nieredukowania poznawanej rzeczywistości do jakiegoś jednego elementu lub ich zestawu („kultury”, „nieświadomości”, "mózgu" itd.) oraz przekonanie, że poznanie polega na podążaniu za aktorem. W różnych pracach Latoura występuje wiele, często enigmatycznych, definicji tego ostatniego pojęcia, na pewno jednak francuski filozof przystałby na stwierdzenie, że aktorem jest to, co działa, a co uwidacznia się w zmianie wprowadzonej w otoczeniu (natomiast poznaniem jest podążanie za tymi zmianami) ${ }^{12}$. Jak pisał w Nadziei Pandory:

Wydawnictwo Naukowe UMK, Toruń 2015. Wspomniane przeze mnie teksty to Granice anarchizmu interpretacyjnego Szahaja (opublikowane najpierw w "Tekstach Drugich", a następnie przedrukowane w książce O interpretacji [Universitas, Kraków 2014]) oraz Interpretacja i literatura Markowskiego („Teksty Drugie” $2001 \mathrm{nr}$ 5).

B. Latour Splatając na nowo to, co społeczne. Wprowadzenie do teorii aktora-sieci, przeł. A. Derra, K. Abriszewski, Universitas, Kraków 2010, s. 130, wyróżnienie P.B.

11 Czytelnik zainteresowany ANT może sięgnąć przede wszystkim do książki Krzysztofa Abriszewskiego Poznanie, zbiorowość, polityka Analiza teorii aktora-sieci Bruno Latoura (Universitas, Kraków 2008) oraz pracy Grahama Harmana Książę sieci. Bruno Latour i metafizyka (przeł. G. Czemiel i M. Rychter, Fundacja Augusta hrabiego Cieszkowskiego, Warszawa 2016). Świetnym przykładem praktykowania ANT są prace autorów z kręgu "toruńskiej szkoły konstruktywizmu” (zob. Toruńska szkoła konstruktywizmu. Manifest, w: Horyzonty konstruktywizmu, s. 125-126). 
nie istnieje żaden inny sposób, aby zdefiniować aktora niż przez jego działania, tak jak nie ma sposobu, by zdefiniować działania inaczej niż przez dociekanie, jacy inni aktorzy zostali zmodyfikowani, przekształceni, zaniepokojeni czy stworzeni dzięki postaci, która nas interesuje. ${ }^{13}$

Używane przeze mnie inne pojęcia ze słownika ANT będę wyjaśniał każdorazowo w momencie ich pojawienia się w tekście.

\section{2.}

Teresy Michałowskiej opis Bogurodzicy to modelowy opis filologiczny, który składa się z trzech przeplatających się ze sobą etapów: 1) analizy przekazów i ustalenia kształtu tekstu, 2) odczytania znaczeń słów i 3) eksplikacji poszczególnych partii oraz całości tekstu. Charakteryzując pracę badaczki z pierwszego etapu, będę posługiwał się pojęciem interpretacji w szerokim jego rozumieniu (jako wszelkiej czynności poznawczej, która polega na umieszczeniu badanego przedmiotu w jakimś kontekście), natomiast drugi i trzeci etap to interpretacja w rozumieniu stricte literaturoznawczym, czyli konkretyzowanie wszelkich niejasnych fragmentów tekstu (zarówno słów, jak i większych jego partii, zarówno znaczeń, jak i sensów).Tego rozróżnienia nie wolno mylić z tym, które zastosowałem powyżej, gdy pisałem o dwóch rozumieniach interpretacji u Fisha i Szahaja, tam węższe rozumienie interpretacji oznaczało nakładanie przed-sądów na to, co czytane.

Michałowska artykułuje pewien domysł, hipotezę co do kształtu tekstu pieśni, o której warto pomyśleć przez pryzmat Latourowsko-Whiteheadowskich pojęć propozycji (angielskie proposition polscy tłumacze oddają także jako „sąd"14) i ar ty kula cji.

Francuski filozof potrzebował ich do tego, by przeformułować pojęcie „przedmiotu”. O ile przedmiot to coś stałego i niezależnego od konstruowania, o tyle propozycja, przeciwnie, jest dokonanym przez kogoś „mariażem"15 przedmiotów, który to mariaż zmienia ich charakterystykę dzięki nowej artykulacji. Odnosząc się do pracy Pasteura, możemy powiedzieć, że propozycjami są Pasteur, fermentacja kwasu mlekowego, laboratorium

B. Latour Nadzieja Pandory, s. 159.

Tak w polskim przekładzie książki Grahama Harmana Książę sieci. Bruno Latour i metafizyka, s. 135. 
w Lille, natomiast artykulacją jest to, co z fermentacją robi Pasteur i jego laboratorium, oraz to, co z Pasteurem i jego laboratorium robi fermentacja. Propozycją jest także (to inny przykład z Nadziei Pandory) grudka ziemi wykopana w Puszczy Amazońskiej, natomiast artykulacją właściwości gleby, ujawniające się dzięki umieszczeniu jej w pedokomparatorze (urządzeniu służącym do analizy gleby).

Propozycjonalno-artykulacyjny charakter ma również czynność znana każdemu edytorowi, czyli ustalenie kształtu tekstu. Michałowska na stronie 281 swojego podręcznika nie umieszcza tzw. przekazu kcyńskiego Bogurodzicy (nie jest w stanie tego zrobić), lecz własną jego artykulację. Przekaz kcyński to anonimowy autograf sporządzony na tylnej wyklejce oprawy kodeksu, w którym słowom pieśni towarzyszy zapis nutowy. Ów przedmiot zamienia się w propozycję - trzystrofową pieśn - w momencie zetknięcia się z badaczką, która artykułuje rękopiśmienny zapis pod postacią zapisu drukowanego ${ }^{16}$. Skąd wybór takiej właśnie formy? Michałowska nie podaje przyczyn, które skłoniły ją do przyjęcia takiego, a nie innego podziału, z dużym jednak prawdopodobieństwem można stwierdzić, że segmentacja Bogurodzicy na strofy wynikała przede wszystkim z przekonania, że przekaz kcyński jest tylko przekazem właśnie, a nie tekstem pierwotnym. Przekaz kcyński nie został podzielony na strofy na przykład z powodu konieczności umieszczenia pieśni w miejscu tak nietypowym jak wyklejka oprawy kodeksu" ${ }^{17}$, natomiast tekst wcześniejszy mógł mieć formę więcej niż jednozwrotkową, ponieważ „[s]truktura tekstu zdaje się naśladować popularny w zachodnioeuropejskich tropach do Kyrie schemat zwrotkowy”, który „budowany był według zasady trójkowej" $(288)^{18}$.

16 Zob. T. Michałowska Średniowiecze, Wydawnictwo Naukowe PWN, Warszawa 2000, s. 281. Wszystkie cytaty pochodzą z tego wydania; w nawiasie obok cytatu podaję numer strony.

17 Zob. A. Czyż Bogu rodzicy aluzje biblijne. Cudze słowo arcypieśni, w: tegoż Rojny i gwarny blask kultury. Literacka varietas i historyczne multum tekstów, Uniwersytet Przyrodniczo-Humanistyczny w Siedlcach, Siedlce 2019, S. 159.

18 Inaczej uważa Krzysztof Obremski, który w studium Część archaiczna pieśni ojczystej: „wyrafinowany artyzm" a majuskuły jako znaki delimitacji wiersza (źródło versus imitacyjne konstrukcje) („Litteraria Copernicana” 2016 nr 3), zestawiwszy ze sobą różne przyjęte przez mediewistów zapisy Bogurodzicy, twierdzi, że są one próbami wytworzenia czegoś, co pierwotnie miało zupełnie inną postać, wynikającymi z pragnienia dowiedzenia artyzmu pieśni (tamże, s. 101). Twierdzenie Obremskiego to właśnie przykład konstruktywizmu, tak jak pojmował go Hacking: odświeżającego i inspirującego, lecz ostatecznie nieprawdziwego, bo przypisującego sprawczość tylko jednemu elementowi opozycji świat (tekst) - umysł (czytelnik). Ani Michałowska, ani inni badacze nie wytworzyli swoich Bogurodzic, ponieważ chcieli dowieść, iż jest 
Michałowska (śladem innych badaczy) na nowo artykułuje propozycję, jaką w momencie zetknięcia się z jej decyzjami staje się rękopis kcyński. Każda nowa artykulacja powoduje utratę pewnych i pojawienie się innych właściwości. Autorka Średniowiecza odejmuje materialność autografu i wszystko to, co owa materialność mogłaby uczynić z czytelnikiem poddanym jej wpływowi, dodaje natomiast większą czytelność pieśni oraz ujawniony przez podział na strofy związek Bogurodzicy z łacińskimi pieśniami liturgicznym ${ }^{19}$. Artykulacja rękopiśmienności jako drukowalności jest efektem decyzji badacza, nie ma nic wspólnego z przemocą wobec tekstu, po pierwsze, dlatego że „uciszenie" rękopiśmienności pozwala na wyłonienie się (wyartykułowanie) tych własności tekstu, których nie ma on jako jednostrofowy zapis odręczny, a po drugie, dlatego że interpretatorka nie jest tu jedynym działającym aktorem: sprawstwo przynależy zarówno jej, jak i materialności, drukowalności, pozostałym badaczom (za którymi przejmuje taki, a nie inny zapis) oraz łacińskim pieśniom liturgicznym.

Punktem wyjścia do eksplikacji znaczeń tak wyartykułowanego zapisu Bogurodzicy jest przekonanie, że sens tekstu nie jest dany, lecz zadany (zob.s. 281), stanowiące podstawę większości definicji interpretacji w jej wąskim, współcześnie w literaturoznawstwie uformowanym kształcie. Fakt, że sens dzieła (a w wypadku dzieł dawnych niejednokrotnie znaczenie poszczególnych słów) jest nie-obecny, umożliwił fishowsko zorientowanym konstruktywistom stwierdzenie, że zamiana nie-obecności na obecność to efekt jej narzucenia, nałożenia, wyprodukowania przez czytelnika, oraz wynikającą stąd implikację, iż jedynie czytelnik jest sprawczy podczas lektury. Poniżej postaram się pokazać, że tak nie jest.

Pierwszą interpretacyjną operacją Teresy Michałowskiej jest połączenie słowa „bogurodzica” (ono samo pozostaje artykulacją przekazu kcyńskiego, w którym zamiast jednego pojawiają się dwa wyrazy: „bogu” i „rodzica”20) ze słowami „dziewica” i „matka” oraz potraktowanie słów „Bogiem sławiena” oraz „zwolena” jako określeń odnoszących się do Bogurodzicy. Następnie

arcydziełem, ale dlatego że podjęli pewną współpracę z tekstem, który na mocy przyjętych przez nich hipotez okazuje się tylko elementem łańcucha przekształceń (tekst pierwotny $\rightarrow$ jego wersja w przekazie kcyńskim $\rightarrow$ próba rekonstrukcji tekstu pierwotnego). cy", przeł. A. Gorzkowski, „Pamiętnik Literacki” 2005 Z. 2, s. 7. 
autorka przechodzi do wyjaśnienia pochodzenia słowa „bogurodzica” przez wskazanie, że jest to jeden z najstarszych w pieśni wyrazów i

jego pochodzenie wiąże się ze starocerkiewno-słowiańskim „bogorodica" (z gr. Theotókos), zapożyczonym przez Czechów w okresie dominacji u nich liturgii słowiańskiej i zapewne z Czech przeniesionym do dawnej polszczyzny. Podobnie jak w języku czeskim starsze „boho-” mogło być zastępowane młodszym „bohu-”, tak też i w polskim obok wcześniejszego „bogo-" pojawiło się późniejsze „bogu-”; ślady tych procesów zachowały się w wariantowych formach niektórych imion, np. „Bohomil”/ „Bohumil” oraz „Bogomił”/ „Bogumił”. Prócz obocznych: „bogorodzica”/ „bogurodzica" zanotowano w Polsce XV wieku jeszcze inną postać wyrazu: „bogarodzica”. „Rodzica” Chrystusa została też nazwana Jego „matką". Słowo to było zdrobnieniem wcześniejszego "mać", ale w XIV wieku pojawiało się już niekiedy bez owego spieszczonego znaczenia; w pieśni zdaje się jeszcze sens ten zachowywać. Zdrobnieniem jest także inne określenie Maryi: „dziewica”, odpowiadające dzisiejszym słowom „dzieweczka”, „panienka”. Określenie „Bogiem sławiena” można rozumieć jako „przez Boga uwielbiona”, zaś przymiotnik „zwolena” - jako „wybrana”. Na uwagę zasługuje imię Bogurodzicy: „Maria” (wymawiane trójzgłoskowo: „Maryja"), przejęte z łaciny i stopniowo wypierające wcześniejszą, rodzimą formę „Marza” (ze spieszczeniami: Masza, Maszka), zachowującą żywotność jeszcze w początkach XV wieku. (282-283)

Ten dłuższy fragment uznaję za reprezentatywny również wobec innych praktyk interpretacyjnych Michałowskiej. Chciałbym w nim zwrócić uwagę na dwie sprawy doskonale znane badaczom z kręgu ANT, które znowu sytuują się jako poglądy opozycyjne względem epistemologii konstruktywistycznej. Metaforą, której Latour użył do opisu relacji epistemologicznej, była metafora umysłu w słoju, implikująca, że poznanie to nawiązywana przez język relacja między dwoma bytami: podmiotem i przedmiotem, z których jedynie pierwszy jest sprawczy ${ }^{21}$. Praktyka badawcza, której reprezentację stanowi cytat ze Średniowiecza, pokazuje, że w poznaniu naukowym nie działa tylko jeden aktor (tekst lub czytelnik) ${ }^{22}$. Zapewne pisząc ten fragment, Teresa Michałowska

21 Zob. B. Latour Nadzieja Pandory, s. 32-39.

22 Zob. B. Latour Science in action. How to follow scientists and engineers through society, Harvard Univeristy Press, Cambridge, MA-London 1987, s. 31. 
siedziała przy biurku odizolowana od innych ludzi, ale przecież podczas tego zajęcia pracowała również z innymi badaczami, przekładając ich ustalenia uobecnione w napisanych przez nich tekstach - na swój tekst. I nie chodzi mi tutaj o dobrze znaną sprawę, że w procesie poznawczym zawsze jesteśmy zanurzeni w jakiejś wspólnocie interpretacyjnej, a więc że badaczka, pisząc Średniowiecze, podzielała z jakimiś ludźmi te same presupozycje interpretacyjne ${ }^{23}$. Pragnę zwrócić uwagę na coś mniej oczywistego. Wszędzie tam, gdzie Michałowska pisze o języku scs, języku greckim, czeskim, historii Czech, historii liturgii i relacjach polsko-czeskich, uobecnia ona zarazem konkretne, jednostkowe propozycje niesprowadzające się do ponadindywidualnych „,norm”, ,procedur”, ,kategorii” czy „presupozycji” (bardziej widoczne byłoby to nie w podręczniku, jakim jest Średniowiecze, ale typowym tekście naukowym, którego ważną cechą są przypisy, będące miejscem uobecnienia cudzej pracy $^{24}$ ). Taką operację łączenia heterogenicznych elementów w jedną całość w ANT określa się jako mobilizowanie zasobów i pojmuje jako sposób, w który teksty zyskują siłę 25 . Nie jest to siła pojęta jako przemoc, lecz siła przekonywania. Uzyskuje się ją dzięki wielości zasobów (propozycji) połączonych w jedną, emergentną całość (artykulacji).

Po ustaleniu pochodzenia słowa „bogurodzica” Michałowska przechodzi do eksplikacji dwóch pierwszych wersów pieśni. Stwierdza, że „określenie «Bogiem sławiena» można rozumieć jako «przez Boga uwielbiona», przymiotnik «zwolena» zaś jako «wybrana»", a wszystkie te słowa odnosi do Maryi. Następnie tłumaczy sens całej strofy, w której „Maryja występuje [...] jako p o śre d n i c z ka między modlącym się ludem a swym Synem, dwukrotnie nazwanym Bogiem («Bogu-rodzica»; «Bogiem - sławiena»), a raz «gospodzinem»" (283; wyróżnienie P.B.). Pierwszym aktorem, za którym podąża Michałowska, są zmaterializowane w tekście Bogurodzicy reguły semantyki i gramatyki - to bardziej one niż partykularne uprzedzenia, przed-sądy, interesy czy cele zanurzonej we wspólnocie interpretacyjnej autorki,

23 Wbrew pozorom o tego rodzaju abstrakcyjność, a nie o konkretny zbiór ludzi chodzi w Fishowskim pojęciu wspólnoty interpretacyjnej. Zob. S. Wójtowicz Neopragmatyzm Stanleya Fisha a polskie spory o kształt literaturoznawstwa po 1989 roku, Wydawnictwo Nauka i Innowacje, Poznań 2014, s. 40.

24 Na temat przypisów por.: K. Abriszewski Poznanie, zbiorowość, polityka, s. 135; B. Latour Science in action, s. 33 .

25 Zob. np. J. Law The heterogenity of texts, w: Mapping the dynamics of science and technology, ed. by M. Callon, J. Law, A. Rip, Palgrave Macmillan, London 1986, s. 79. 
jak chcieliby konstruktywiści społeczni, nakazały połączyć słowo „zwolena” ze współczesnym słowem „wybrana” oraz z główną bohaterką pieśni, czyli Maryją. Kolejną operacją wykonaną przez badaczkę było przełożenie mnogości znaczeń poszczególnych słów na jedną kategorię - „pośredniczki” która dotyczyć ma ich wszystkich. Tego rodzaju redukcję określa się w bliskiej Latourowi semiotyce Greimasa izotopią. Z punktu widzenia Latoura każda redukcja złożoności potrzebna jest do tego, aby łatwiej było zapanować nad tym, co badane, i łatwiej tym czymś manipulować. Gleboznawca badający ziemię w Puszczy Amazońskiej nie bada całej gleby, lecz tylko jej próbkę to dzięki temu będzie mógł glebę umieścić w pedokomparatorze i określić jej cechy charakterystyczne. Na podobnej zasadzie działa interpretator pojedynczego tekstu. Teresa Michałowska znaczenia wielu słów przekłada na jedną całość - izotopię „pośredniczka” - która oddaje ich sens. Wydaje się oczywiste, że kilkanaście słów umieszczonych w jednym pojęciu odbędzie bardziej owocną wędrówkę po różnych kontekstach, inspirując do powstania innych tekstów - m.in. teologicznych czy historycznoliterackich - a na ich podstawie na przykład do wzbogacenia przekonań religijnych. Dysponując słowem „pośredniczka”, możemy też wrócić do tekstu, zadać mu różne pytania, których nie moglibyśmy zadać bez niego.

Dotychczasowe koncepcje interpretacji z reguły mieściły się w obrębie modelu wertykalnego, zakładającego, że sens albo znajduje gdzieś w środku tekstu, skąd należy go wydobyć na powierzchnię - jak chcieli esencjaliści - albo też jest wpisywany czy narzucany na tekst, jak twierdzili konstruktywiści $^{26}$. Przedstawione powyżej streszczenie działań Teresy Michałowskiej pokazuje, że interpretacja to proces odbywający się w świecie całkowicie płaskim $^{27}$ - polega on na tworzeniu sieci przez horyzontalne przyłączanie jednego elementu do drugiego. Pozwala ono także sproblematyzować jeszcze jedno silnie obecne w konstruktywistycznych teoriach interpretacji przekonanie, zgodnie z którym nie możemy rozróżnić kontekstu macierzystego i adaptacyjnego ${ }^{28}$. Zobaczyliśmy, że aktywność Teresy Michałowskiej to aktywność kogoś, kto współdziała z tym, co dane, pozwalając na sprawstwo zarówno

26 Pojęcia wertykalnego i horyzontalnego modelu interpretacji przejąłem od Ryszarda Nycza. Zob. tegoż Poetyka doświadczenia. Teoria - nowoczesność - literatura, Wydawnictwo IBL PAN, Warszawa 2012, s. 126. tyka, s. 276-287.

28 A. Szahaj O interpretacji, s. 20. 
tekstowi, jak i innym aktorom. Nie dzięki sobie, ale przede wszystkim dzięki nim dostrzegła ona, że słowo „zwolena” oznacza „wybrana” oraz że łączy się ono z Maryją, co pozwoliło jej od kryć również kontekst macierzysty, bo przecież z bardzo dużym prawdopodobieństwem możemy orzec, że takie właśnie połączenia założył dla swojego tekstu jego anonimowy autor. Czy jest to partykularna interpretacja? Ktoś, kto używa tego pojęcia, zakłada jednak jakąś różnicę między swoją interpretacją i tekstem, a w tym wypadku tej różnicy nie ma: Teresa Michałowska, współdziałając z tekstem, raczej po prostu odkrywa, niż konstruuje lub, jeśli ktoś woli, konstruuje sens tak, jak zaplanował dla swojego tekstu jego autor - co na jedno wychodzi.

Byłoby z mojej strony nieuczciwością poprzestać tylko na tym przykładzie. Często rację mają antyesencjaliści, twierdząc, że interpretacje są efektem konstrukcji, w której partykularne wybory badacza niejako przykrywają to, co zostało powiedziane w tekście. O ile u Michałowskiej tego rodzaju odczytań w zasadzie nie znajdziemy, o tyle wręcz wspiera się na nich fascynująca i najbardziej skrupulatna, spośród tych, jakie dotychczas powstały, lektura pieśni przedstawionej przez Zdzisławę Krążyńską i Tomasza Mikę w artykule Architektura „Bogurodzicy”. Poświęcę jej teraz trochę miejsca, paradoksalnie zrobię to jednak, by pokazać, że również tam, gdzie pojawia się owo przykrywanie tekstu przez zamysł interpretatora, nie jest efektem działania tylko jednego aktora - czytelnika.

W swojej interpretacji pierwszego wersu pieśni autorzy piszą, że wybór formy celownikowej złożenia „Bogu-rodzica” nie był przypadkowy (wiadomo skądinąd, że dopuszczalne były w tamtym czasie również formy „Boga-rodzica” i „Bogo-rodzica”29) i że podkreśla on „służebną rolę rodzicy, więcej - określono [tą formą] kierunek przyporządkowania: świata ludzkiego do boskiego, a nie na odwrót". Służebność rodzicy została też wyartykułowana przez samą formę pierwszego wersu. Nie dość na tym. Według Krążyńskiej i Miki istotne dla odczytania pierwszej strofy pieśni jest otoczenie wyrazów "rodzica” - „dziewica” wyrazem „Bóg”, co sugeruje „zawieranie się Maryi w Bogu"30, a także to że sama forma pojawiających się w nim słów oraz ich kolejność wprowadzają pewne informacje naddane: informują nas dokładnie

Przykłady podaje Ewa Ostrowska. Zob. tejże Wstęp i komentarz językowy, w: Bogurodzica, oprac. J. Woronczak, wstęp językoznawczy E. Ostrowska, oprac. muzyczne H. Feicht, Zakład Narodowy im. Ossolińskich i Wydawnictwo Polskiej Akademii Nauk, Wrocław-WarszawaKraków 1962, s. 27. 
o strukturze relacji między światem ludzkim a światem boskim. Ta logika lektury wynika z założenia, że Bogurodzica to mały traktat teologiczny, który kondensuje wiele treści w bardzo zwięzłej formie, co ostatecznie doprowadza Krążyńską i Mikę do interpretacji formy pieśni, w której traktuje się ją jako znaczącą (ustanawia się na przykład zależność między dwustrofową formą pieśni a „dualnością treści" ${ }^{\text {31) }}$.

Nie mam wątpliwości, że interpretacja Krążyńskiej i Miki jest nadinterpretacją (niezwykle co prawda fascynującą!), to znaczy taką lekturą, która nie respektuje zasady ekonomii wyjaśniania, mówiącej, że z dwóch możliwych interpretacji - prostszej i bardziej prawdopodobnej oraz bardziej złożonej i mniej prawdopodobnej - powinniśmy wybrać tę pierwszą. Świetnie też ich artykuł pokazuje zasadność podstawowego twierdzenia takich konstruktywistów, jak Szahaj, Wójtowicz czy Fish, o tym, że interpretacja to wpisywanie w tekst swoich własnych presupozycji interpretacyjnych. Chciałbym jednak zwrócić uwagę na rzecz przez konstruktywistów niezauważaną - na to, że nawet nadinterpretacja potrzebuje działania tekstu oraz a u tora te go tekstu. Aby było możliwe stworzenie nadinterpretacji, mówiącej, że formą „Bogu-” (wybraną z repertuaru, w którym znalazły się także formy „Bogo-” i „Boga-”) intencjonalnie podkreślono służebną rolę rodzicy, najpierw ktoś inny musi napisać słowo zakończone na „u”, a nie „a” czy „o”. Nadinterpretacja przypisująca sens kolejności słów również nie zostaje po prostu tekstowi narzucona, lecz sprowokowana, zasugerowana przez samą tę kolejność. Gdyby wyrazy „rodzica” i „dziewica” nie były otoczone przez wyraz „Bóg", nie można by było powiedzieć, że matka Boga zawiera się w Bogu. Innymi słowy i paradoksalnie rzecz ujmując, Krążyńska i Mika, tworząc swoje nadinterpretacje, musieli bardzo dokładnie trzymać się tekstu - jako tego, co je umożliwiając, prowokując czy sugerując, także działa.

Wiem, co odpowiedzą konstruktywiści: moja koncepcja, jakoby to tekst sugerował swoją własną nadinterpretację, jest nietrafna, ostatecznie bowiem to nadinterpretator tworzy nadinterpretację na podstawie wcześniejszej interpretacji, o której interpretatywności zapomina, myśląc, że działa sam tekst. Prościej mówiąc: aby ktoś mógł zinterpretować otoczenie słów odnoszących się do Maryi słowem „Bóg” jako zawieranie się Maryi w Bogu, wcześniej musiał dysponować ideami kolejności, zawierania się itd., ostatecznie więc to owe zdeponowane w umyśle interpretatora idee działają, a nie tekst. Wyobraźmy sobie jednak, że kolejność słów w pierwszym wersie Bogurodzicy 
jest inna niż w przekazach, które dotrwały do naszych czasów, i wygląda tak: „rodzica”,,Bóg”,,,Bogiem”,, dziewica”. Teraz zapytajmy, czy jest możliwa interpretacja tego ciąu jako zawierania się Maryi w Bogu? Najbardziej zdeklarowany zwolennik Fishowskiej zasady "Interpretation is the only game in town" będzie musiał odpowiedzieć, że coś stawia opór tej interpretacji. Czym jest to coś? Konstruktywista odpowie, że kultura, a dokładniej zinterioryzowany w podmiocie nakaz potraktowania wyrażenia "zawieranie się Maryi w Bogu" jako odpowiadającego kolejności „Bogu”,,,rodzica”,,dziewica”,„Bogiem”, a nie odpowiadający kolejności „rodzica”,,,Bóg”,,,Bogiem”,,,matka”. Dlaczego jednak uznając, że działa podmiot i dokonująca się w nim interioryzacja, konstruktywiści nie chcą uznać żadnego działania tekstu? Wydaje się, że jak pisał Markiewka, który zainspirował tę część moich rozważań:

Na sprawę możemy więc patrzeć z dwóch stron. Sam tekst [... ] nie wpłynąłby na zmianę moich opinii, gdyby w moim umyśle nie pojawiły się przekonania [...].Z drugiej strony same przekonania [...] nie zmieniłyby mojej opinii, gdybym nie trafił na odpowiedni tekst. [...] nie argumentuję na rzecz tezy, iż nasze przekonania czy konteksty nie wpływają na interpretację. Twierdzę jedynie, że teksty [...] także to robią. ${ }^{32}$

\section{3.}

Przedstawione tutaj studium miało na celu zmianę szeroko rozpowszechnionego wyobrażenia na temat tego, czym jest interpretacja. Dwa główne jej modele - realistyczny i konstruktywistyczny - są modelami zarazem wertykalnymi i redukcjonistycznymi. Wertykalnymi, bo zakładają, że sens

Tamże, s. 68. Pogląd Markiewki nie jest oryginalny, przypomina bowiem, choć sam autor się na nią nie powołuje, dyskusję między Richardem Rortym i Bjørnem Bambergiem zawartą w tomie Rorty and his critics. Mówiąc w największym skrócie (i licząc na to, że dobrze zrozumiałem tekst Bamberga, napisany niezbyt mi bliskim językiem filozofii analitycznej), Bamberg krytykuje pogląd, zgodnie z którym prawda nie jest kwestią referencji, ale preferencji. Co najciekawsze, z Bambergiem zgadza się sam Rorty, pisząc, że poczuł się przez jego tekst "oświecony", i dodając: „Dzięki niemu uświadomiłem sobie, że powinienem był zaakceptować stanowisko Davidsona głoszące, iż większość naszych przekonań dotyczących czegokolwiek (śniegu, molekuł, prawa moralnego) może być prawdziwa tylko w odniesieniu do tej rzeczy" (R. Rorty Response to Bjørn Bamberg, w: Rorty and his critics, ed. by R.B. Brandom, Blackwell Publishers, MaldenOxford 2000, s. 374). Wszystko, co twierdzimy o jakiejś rzeczy, musi dotyczyć tej rzeczy, musi więc ona zaistnieć, abyśmy mogli się o niej wypowiadać, a gdy zniknie - zmienią się również nasze opisy. 
wyłania się niejako "od dołu” - jak w wariancie realistycznym, w którym interpretator go „wydobywa"33 - lub „z góry”, jak w wariancie konstruktywistycznym, w którym sens jest efektem narzucania go na bezkształtną materię tekstu przez jego interpretatora. Redukcjonistycznymi, bo ograniczają one liczbę aktorów interpretacji do dwóch: tekstu i kontekstu macierzystego (wariant realistyczny) interpretatora i kultury (wariant konstruktywistyczny). Mam nadzieję, że udało mi się Czytelnika przekonać, iż sensowniejsze jest inne, horyzontalne, wyobrażenie tego, co się dzieje, kiedy interpretujemy. W modelu horyzontalnym interpretacja to artykulacja propozycji, czyli takie działanie z tym, co tekstowo dane, które nie jest całkowicie zdeterminowane przez podmiot, to bowiem, co tekstowo dane, również współokreśla działania podmiotu.

Procedura interpretacji polega na przyłączaniu jednego aktora do drugiego i budowaniu z nich sieciin ${ }^{34}$ Sieci mogą być mocne lub słabe, a ich siła jest pochodną liczby tworzących je aktorów oraz charakteru wiązań między nimi. To, co podczas interpretacji tworzy sieć, nie może być zredukowane do kontekstu (choć nie szedłbym tak daleko jak Rita Felski, która twierdzi, że „kontekst jest do bani" ${ }^{35}$ ), ponieważ w interpretację tekstu, jak starałem się pokazać, zaangażowani są także inni aktorzy:

- media (to, czy interpretujemy rękopis czy druk oraz, już na etapie druku, wersję dwu- lub trzystrofową),

- autorzy innych opracowań oraz ich teksty,

- sam tekst (choć nie „tekst sam w sobie”!),

- jego autor oraz, last but not least,

- autor interpretacji.

To, że wszystkie te byty działają, ujawnia się podczas eksperymentu polegającego na usunięciu lub zamianie jednego z nich. Jak działają autorzy innych opracowań? Dostarczają nam wiedzy, bez której pewne elementy tekstu pozostaną dla nas nieczytelne, przez co nie będziemy w stanie potraktować ich jako propozycji do artykulacji. Jak działa tekst? Zobaczyliśmy, że gdy zamienimy kolejność słów pieśni, pewne odczytania zostaną uniemożliwione. Jak działa autor? Bez wiedzy o nim nie połączymy tekstu z konkretnymi znaczeniami. (Gdybyśmy zrobili eksperyment i zamiast autora średniowiecznego

33 Zob. J. Sławiński Interpretacja, hasło w: Słownik terminów literackich, red. J. Sławiński, Wrocław 2008, s. 217. 
wyobrazili sobie, że Bogurodzica została napisana przez dwudziestowiecznego poetę, zmieni się sens całości, którą odczytamy jako archaizującą stylizację). Jak działa medium? Ten, kto czytał rękopis kcyński (a nie jego drukowaną artykulację), ma szansę doświadczyć tego, co historycy nazywają „doświadczeniem historycznym", które pojawia się w momencie kontaktu z jakimś artefaktem z przeszłości. Jest to oszołomienie chwilą, wywołane tym, że ma się „wrażenie bycia w bezpośrednim i absolutnie autentycznym kontakcie z przeszłością"36. Czy to doświadczenie wzniosłości ma wpływ na interpretację? Jestem przekonany, że tak, może bowiem wzmacniać przeświadczenie, iż ma się do czynienia z czymś o niezwykłej wadze, a przez to skłaniać do znacznie poważniejszego traktowania tekstu, niż on na to w rzeczywistości zasługuje ${ }^{37}$.

Wszystko to nie oznacza oczywiście, że należy całkowicie porzucić konstruktywizm akcentujący rolę interpretatora i wspólnoty interpretacyjnej w interpretacji w kierunku jakiegoś literaturoznawczego odpowiednika determinizmu technologicznego. Wspólnoty interpretacyjne oraz indywidualni interpretatorzy także działają, czego mój tekst nie mógł pokazać w wystarczającym stopniu, bo też był polemiczny względem konstruktywizmu oraz bazował na przykładzie, w którym niewywiedzione z tekstu decyzje interpretacyjne zostały ograniczone do minimum. Zobaczyliśmy, że media, inni autorzy i ich teksty, sam tekst oraz autor nie determinują działania interpretatora, redukując go do roli ślepego ich narzędzia. To raczej „,autoryzowanie, pozwalanie na nie, umożliwianie go, zachęcanie do niego, wyrażanie na nie zgody, sugerowanie mu go, wpływanie na nie"38 - inne sposoby współpracy z czytelnikiem. Współpraca ta jednak istnieje, toteż gdy wypowiadamy się o interpretacji, nie powinniśmy o tym zapominać, porzucając dwa dotychczasowe stanowiska w sporze o nią.

F. Ankersmit Modernistyczna prawda, postmodernistyczne przedstawienie i po-postmodernistyczne doświadczenie, przeł. E. Domańska, w: tegoż Narracja, reprezentacja, doświadczenie. Studia z teorii historiografii, Universitas, Kraków 2004, S. 213.

37 Zob. K. Obremski, Część archaiczna pieśni ojczystej. 


\section{Abstract}

\section{Paweł Bohuszewicz}

NICOLAUS COPERNICUS UNIVERSITY (TORUŃ)

Actors of Interpretation

Bohuszewicz polemicises with the constructivist notion of interpretation proposed in Latourian actor-network theory. Based on a case study (Teresa Michałowska's interpretation of Bogurodzica) Bohuszewicz outlines a new concept of interpretation where more actors are at play than previously assumed. This concept replaces the current vertical notion with a horizontal one.

\section{Keywords}

interpretation, social constructivism, actor-network theory, Bogurodzica 